\title{
Editorial
}

Alan J. Abramson, Mirae Kim and Stefan Toepler* Staying the Course: Editorial Statement on the Future Direction of Nonprofit Policy Forum

\author{
https://doi.org/10.1515/npf-2021-0028
}

We are pleased to begin our tenure as Co-Editors-in-Chief of Nonprofit Policy Forum $(N P F)$, seeking to build on the terrific legacy of Founding Editor Dennis Young and Founding Managing Editor Linda Serra who guided the journal from its first issue in 2010 through volume 12, issue 2 in July 2021.

\section{Thematic Foci}

At least in the near-term, we plan to continue to focus $N P F$ on the major topics addressed in the journal's first decade (see Young 2021). As identified in Box 1, these topics include: 1) various dimensions of the government/nonprofit relationship comprising but not limited to: government funding of nonprofit service delivery, government regulation of the nonprofit sector, and nonprofit advocacy activities aimed at influencing government policy; 2) issues related to blurring sector boundaries such as: hybrid organizational forms, social enterprises, and social investment; 3) transnational non-governmental organizations and crossnational NGO/nonprofit issues; and 4) developments in particular policy fields (e.g., health, human services, arts) and their effects on nonprofits.

Specifically, we anticipate that the three pillars of government/nonprofit relations will remain the principal base of the journal's content. The first pillar-government financing and nonprofit provision of services-covers: general government/nonprofit relationship issues, both cooperative and contentious; national-level approaches and

\footnotetext{
*Corresponding author: Stefan Toepler, Schar School of Policy and Government, George Mason University, 3434 Washington Blvd, MSN 3B1, Arlington 22201, VA, USA, E-mail: stoepler@gmu.edu Alan J. Abramson, Schar School of Policy and Government, George Mason University, 3351 Fairfax Drive, Room 608 - MS 3B1, Arlington 22201, VA, USA

Mirae Kim, Schar School of Policy and Government, George Mason University, Fairfax 220304444, VA, USA
} 
developments; collaborative governance mechanisms; and specific government/ nonprofit partnerships at the local level (e.g., Almog-Bar 2017a; Carboni et al. 2017; Levy and Ketels 2021; Okuyama, Ishida, and Yamauchi 2010; Reuter, Wijkstrom, and von Essen 2012). Purchase-of-service contracting and its effects on nonprofits as well as grants and other tools that governments use to fund nonprofits, such as vouchers or reimbursements, are also important topics under this heading (e.g., Never and Westberg 2017; Saidel 2017; Thornton and Lecy 2019).

\section{Box 1: Nonprofit Policy Forum's Main Topical Areas}

1. Dimensions of Government/Nonprofit Relations

a. Financing and Provision of Services

- government funding, including contracting and other government tools

- collaborative governance arrangements

- effects of government funding on nonprofits

- complementary, supplementary \& adversarial relations

b. Regulation and Accountability

- analysis and evaluation of tax policies

- impact of law and regulatory policies on nonprofits

- self-regulation and accountability, sector infrastructure

- reform needs and gaps in law and regulation (policy neglect)

- effects of securitization on nonprofits

c. Advocacy and Consultation

- policy advocacy and lobbying

- civic engagement

- political activism and voter mobilization

- contributions to democratization

- involvement in consultative bodies, task forces, etc.

- social movement organizations and social change philanthropy

2. Social Enterprise and Sector Boundaries

a. Hybridity/hybridization

b. Social enterprise and entrepreneurship

c. Social finance and investment

d. Market environments and competition involving nonprofits and for-profits

3. INGOs and Global/Cross-national Issues

4. Developments in Policy Fields and Effects on Nonprofits

Relevant development affecting nonprofits in fields such as human services, health care, social justice, the environment, education, arts and culture, religion, international development, emergency management and homeland security, and philanthropy

Government regulation, as the second pillar, can be just as, and occasionally even more, important than funding policies. Tax policy steers nonprofits and philanthropy into 
addressing various public policy priorities and undergirds the sector's financial viability (e.g., Duquette 2020; Grønbjerg and McGiverin-Bohan 2016; Rooney et al. 2020). But nonprofits are also affected by a broad range of non-fiscal laws and regulations concerning their establishment and operation (DeMattee 2019). Political regimes are changing globally, which has been leading to a regulatory closing of spaces for nonprofits and civil society more generally (e.g., Appe, Barragán, and Telch 2019; Herrold 2016; Katz and Gidron 2021; Simsa 2017, 2019). But the nature of nonprofit action has changed as well, creating significant need for the reform of legal frameworks that largely date to the last millennium. Also of interest here are gaps in government regulation and efforts at voluntary self-regulation to fill them, or accountability initiatives to bridge them (e.g., Anheier and Toepler 2019; Chikoto 2015; Mosley 2016; Prakash 2019).

While the first two pillars principally, though not exclusively, have the government structuring the contours of the government/nonprofit relationship, the third one-advocacy-has nonprofits attempting to influence government programs or policies. We define this pillar expansively with nonprofit lobbying and insider/outsider advocacy activities at the core (e.g., Abdel-Samad 2017; AlmogBar 2017b; Guo and Saxton 2010; Lamothe and Lavastida 2020; Prentice 2018). However, we also consider other forms of social change efforts, political activism, and contributions to democratic practice, elections, and civic engagement as tasks of nonprofits and civil society that seem especially important today (e.g., Alexander and Fernandez 2021; Li and Zhang 2017; Mosley 2016; Saitgalina, Dicke, and Birungi 2020). Governments, on occasion, also invite input from nonprofits through various consultative bodies or mechanisms.

As shown in Table 1, these three pillars combined accounted for $60 \%$ of all published material in NPF (outside of editorials and book reviews) from the journal's beginning through the prior issue (12:2). Beyond these main areas of emphasis, the journal has traditionally featured a few additional topics closely related to nonprofit policy. In particular, the growth of social enterprise over the past three decades or so has had a profound impact on the evolution of nonprofit policy broadly conceived (e.g., Abramson and Billings 2019; Cooney et al. 2016). The social enterprise space encompasses a focus on the business operations of nonprofits with implications for the commercialization, marketization, or economization of the sector (Alexander and Fernandez 2021); the implications for nonprofits of operating in market environments with competition among nonprofits and between nonprofits and for-profits (e.g., Ashley 2014; Harrison and Thornton 2014; Seaman, Wilsker, and Young 2014); and the boundary-blurring and boundary-spanning hybridization of organizations and welfare regimes (e.g., Gidron 2010; Jönsson 2019; Toepler 2018). Hybridization, of course, also entails the development of new social finance and investment mechanisms to foster social innovation on both sides of the nonprofit/for-profit divide (e.g., Albertson et al. 2020; Ferris and Graddy 2020). 
Table 1: Distribution of NPF articles by thematic focus, 2010-2021.

\begin{tabular}{lr}
\hline Government financing and collaboration & $26 \%$ \\
Regulation and accountability & $20 \%$ \\
Advocacy & $14 \%$ \\
Social enterprise and sector boundaries & $10 \%$ \\
INGOs and cross-national issues & $10 \%$ \\
Policy field analyses & $9 \%$ \\
Not elsewhere classified & $9 \%$ \\
\hline
\end{tabular}

The analysis of nonprofit policy in inter- and trans-national perspectives, on the one hand, and from the vantage points of specific policy fields, on the other, are NPF's third and fourth major foci. Transnational NGOs face significantly different policy environments than their domestically-focused counterparts, having to contend at times with conflicting policy environments in their various countries of operation. Government/nonprofit relationships may differ between levels of government within countries as well as between countries. In many non-Western countries, there are additional layers of government, specifically supra-national and foreign government interactions with local NGOs, to take into account in understanding government/ nonprofit relations. United Nations' interventions (e.g., World Health Organization involvement in fighting infectious disease outbreaks in Africa) or foreign official donor agencies pursuing democratization strategies often result in different kinds of interactions with INGOs or local nonprofits than host governments have with these same organizations (e.g., Chikoto 2015; Khan 2016; Pallas and Sidel 2020; Prakash 2019; Shieh 2018). About four out of 10 articles published in NPF thus far (outside of editorials and book reviews) discuss various issues based on cases outside the U.S., and $N P F$ will continue to welcome articles that offer inter- and trans-national perspectives.

Finally, exploring how different policies in different fields (e.g., arts, education, human services, environment) affect nonprofits will also continue to be an important interest of NPF (e.g., Haslam, Nesbit, and Christensen 2019; Henrekson et al. 2020; Smith and Phillips 2016; Wang and AbouAssi 2021). These impacts may depend on the constellation of intergovernmental relations, that is the relative importance that national, regional, and local governments play in shaping the respective policy field; field-specific regulatory and support needs; and the tools of government that are deployed in different fields (e.g., grants vs. contracts vs. vouchers).

\section{Types of Submissions}

Future issues of NPF will stay focused on academically-oriented, full-scale research articles, but we will also continue pursuing special features, alternating 
among policy briefs, research reports, commentaries, case studies, interviews, and book reviews, as outlets for more applied work and venues for presenting novel policy ideas. Guidelines for these different kinds of articles follow:

- Research Articles (peer review, 5000-8000 words): Full, theoretical/conceptual and empirical research articles addressing: the effect of government policies and tools on nonprofits; nonprofit advocacy activities and their effect on policy; civil society and social movements seeking social change; other significant aspects of the government/nonprofit relationship; development and institutional contexts of social enterprise.

- Research Notes (peer review, 3000-4000 words): Research Notes are researchbased, short articles presenting policy-relevant findings or suggesting novel policy approaches with a focus on informing academic debate on the topic. They may be more descriptive than analytical, or present novel ideas or concepts with limited data.

- Policy Briefs (peer review, 3000-4000 words): Policy Briefs present researchinformed discussions of current policies and policy proposals with a focus on informing policy makers. They introduce a policy topic, provide an overview of relevant research, and either advocate for a position or lay out policy options with a recommendation.

- Commentaries (editorial review, 2000-3000 words): Research-informed, opinion-based discussion of contemporary policy developments, current debates in the field, or proposals for policy reform.

- Case studies (peer review, 2000-4000 words): Teaching cases or analytical case studies.

- Interviews (editorial review, 2000-4000 words): Interviews with leaders in the field reflecting on important nonprofit policy issues.

- Book reviews (editorial review, 2000-3000 words): Reviews of recently published books focused on nonprofits and public policy.

In addition to inviting individual submissions, we also welcome proposals for special issues of NPF. These proposals, and other suggestions and comments, can be emailed to us at E-mail: npf@gmu.edu.

\section{Conclusion}

Dennis and Linda laid an outstanding foundation for $N P F$, recognized with a second quartile ranking in the most recent Scopus-based Scimago Journal Ranking, and we expect to build on their legacy and help guide the journal from the Emerging Sources into the Social Science Citation Index. 
The three of us very much look forward to working with our publisher; generous funders at the Association for Research on Nonprofit Organizations and Voluntary Action (ARNOVA), the Hubert H. Humphrey School of Public Affairs at the University of Minnesota, the Jack, Joseph and Morton Mandel School of Applied Social Sciences at Case Western Reserve University, the Urban Institute, and our home base, the Schar School of Policy and Government at George Mason University; editorial board members; authors; and reviewers as we begin an exciting second decade of $N P F$.

Alan Abramson, Mirae Kim, Stefan Toepler

Co-Editors-in-Chief

July 2021

\section{References}

Abdel-Samad, M. 2017. “Legislators' Need for Civil Society Expertise: Tunisian Civil Society Legislative Advocacy Opportunity." Nonprofit Policy Forum 8 (3): 299-319.

Abramson, A. J., and K. C. Billings. 2019. "Challenges Facing Social Enterprises in the United States.” Nonprofit Policy Forum 10 (2), https://doi.org/10.1515/npf-2018-0046.

Albertson, K., C. Fox, C. O'Leary, and G. Painter. 2020. “Towards a Theoretical Framework for Social Impact Bonds.” Nonprofit Policy Forum 11 (2), https://doi.org/10.1515/npf-2019-0056.

Alexander, J., and K. Fernandez. 2021. "The Impact of Neoliberalism on Civil Society and Nonprofit Advocacy." Nonprofit Policy Forum 12 (2): 367-94.

Almog-Bar, M. 2017a. "Civil Society and Nonprofits in the Age of New Public Governance: Current Trends and Their Implications for Theory and Practice." Nonprofit Policy Forum 8 (4): 343-9.

Almog-Bar, M. 2017b. "Insider Status and Outsider Tactics: Advocacy Tactics of Human Service Nonprofits in the Age of New Public Governance." Nonprofit Policy Forum 8 (4): 411-28.

Anheier, H. K., and S. Toepler. 2019. "Policy Neglect: The True Challenge to the Nonprofit Sector." Nonprofit Policy Forum 10 (4), https://doi.org/10.1515/npf-2019-0041.

Appe, S., D. Barragán, and F. Telch. 2019. "Organized Civil Society Under Authoritarian Populism: Cases from Ecuador.” Nonprofit Policy Forum 10 (3), https://doi.org/10.1515/npf-2019-0039.

Ashley, S. 2014. "The Impact of Government Funding on Competition in the Nonprofit Sector: An Integrative Model and Review of Empirical Research." Nonprofit Policy Forum 5 (2): 289-305.

Carboni, J. L., S. Siddiki, C. Koski, and A.-A. Sadiq. 2017. "Using Network Analysis to Identify Key Actors in Collaborative Governance Processes." Nonprofit Policy Forum 8 (2): 133-45.

Chikoto, G. 2015. "Steering International NGOs through Time: The Influence of Temporal Structuring in Government Accountability Requirements." Nonprofit Policy Forum 6 (1): 59-90.

Cooney, K., M. Nyssens, M. O'Shaughnessy, and J. Defourny. 2016. "Public Policies and Work Integration Social Enterprises: The Challenge of Institutionalization in a Neoliberal Era." Nonprofit Policy Forum 7 (4): 415-33.

DeMattee, A. J. 2019. "Toward a Coherent Framework: A Typology and Conceptualization of CSO Regulatory Regimes.” Nonprofit Policy Forum 9 (4), https://doi.org/10.1515/npf-2018-0011. 
Duquette, N. 2020. “A Two-Tiered Charitable Contribution Credit for All American Taxpayers." Nonprofit Policy Forum 11 (4), https://doi.org/10.1515/npf-2019-0063.

Ferris, J. M., and E. A. Graddy. 2020. "Philanthropy and Social Impact: A NPF Mini-Symposium." Nonprofit Policy Forum 11 (2), https://doi.org/10.1515/npf-2020-0025.

Gidron, B. 2010. "Policy Challenges in Light of the Emerging Phenomenon of Social Businesses." Nonprofit Policy Forum 1 (1), https://doi.org/10.2202/2154-3348.1003.

Grønbjerg, K., and K. McGiverin-Bohan. 2016. "Local Government Interest in and Justifications for Collecting Payments-in-Lieu of (Property) Taxes from Charities.” Nonprofit Policy Forum 7 (1): 7-14.

Guo, C., and G. D. Saxton. 2010. "Voice-In, Voice-Out: Constituent Participation and Nonprofit Advocacy." Nonprofit Policy Forum 1 (1), https://doi.org/10.2202/2154-3348.1000.

Harrison, T., and J. Thornton. 2014. "Too Many Nonprofits? An Empirical Approach to Estimating Trends in Nonprofit Demand Density." Nonprofit Policy Forum 5 (2): 213-29.

Haslam, A., R. Nesbit, and R. K. Christensen. 2019. "The Dynamic Impact of Nonprofit Organizations: Are Health-Related Nonprofit Organizations Associated with Improvements in Obesity at the Community Level?" Nonprofit Policy Forum 10 (3), https://doi.org/10.1515/npf-2018-0040.

Henrekson, E., F. O. Andersson, F. Wijkström, and M. R. Ford. 2020. "Civil Society Regimes and School Choice Reforms: Evidence from Sweden and Milwaukee." Nonprofit Policy Forum 11 (1), https://doi.org/10.1515/npf-2019-0042.

Herrold, C. E. 2016. “NGO Policy in Pre-and Post-Mubarak Egypt: Effects on NGOs' Roles in Democracy Promotion.” Nonprofit Policy Forum 7: 189-212.

Jönsson, J. 2019. “Logic Salience in Ideologically-torn Nonprofit Hybrids.” Nonprofit Policy Forum 10 (3), https://doi.org/10.1515/npf-2019-0001.

Katz, H., and B. Gidron. 2021. "Encroachment and Reaction of Civil Society in Non-liberal Democracies: The Case of Israel and the New Israel Fund." Nonprofit Policy Forum, https:// doi.org/10.1515/npf-2020-0043.

Khan, S. 2016. "Re-examining the Policies in the Humanitarian Aid Sector - A Call for Greater "Value Rationality." Nonprofit Policy Forum 7 (1): 15-21.

Lamothe, M., and V. Lavastida. 2020. "Nonprofit Advocacy in the Era of Trump." Nonprofit Policy Forum 11 (3), https://doi.org/10.1515/npf-2020-0018.

Levy, K., and A. Ketels. 2021. "Outsourcing and Networking: Similar Trends in Local State-NPO Cooperation in Germany and China." Nonprofit Policy Forum 12 (2): 243-84.

Li, H., and J. Zhang. 2017. "How do Civic Associations Foster Political Participation? The Role of Scope and Intensity of Organizational Involvement." Nonprofit Policy Forum 8 (1): 3-24.

Mosley, J. E. 2016. “Nonprofit Organizations' Involvement in Participatory Processes: The Need for Democratic Accountability." Nonprofit Policy Forum 7 (1): 77-83.

Never, B., and D. Westberg. 2017. "Moving to Need: The Effect of Federal Contracts on Service Provider Location.” Nonprofit Policy Forum 8 (2): 147-64.

Okuyama, N., Y. Ishida, and N. Yamauchi. 2010. "Public Private Partnership between Local Governments and Nonprofits in Japan." Nonprofit Policy Forum 1 (1), https://doi.org/10. 2202/2154-3348.1011.

Pallas, C. L., and M. Sidel. 2020. "Foreign Aid Reduction and Local Civil Society: Recent Research and Policy Guidance for Donors and International NGOs." Nonprofit Policy Forum 11 (1), https://doi.org/10.1515/npf-2019-0045.

Prakash, A. 2019. “Nonprofit Governance, Public Policy, and the Oxfam Scandal: An Introduction.” Nonprofit Policy Forum 10 (4), https://doi.org/10.1515/npf-2019-0059. 
Prentice, C. R. 2018. "Misreporting Nonprofit Lobbying Engagement and Expenses: Charitable Regulation and Managerial Discretion." Nonprofit Policy Forum 9 (2), https://doi.org/10. 1515/npf-2018-0018.

Reuter, M., F. Wijkstrom, and J. von Essen. 2012. "Policy Tools or Mirrors of Politics. GovernmentVoluntary Sector Compacts in the Post-Welfare State Age." Nonprofit Policy Forum 3 (2), https://doi.org/10.1515/2154-3348.1062.

Rooney, P., S. Zarins, J. Bergdoll, and U. Osili. 2020. "The Impact of Five Different Tax Policy Changes on Household Giving in the United States." Nonprofit Policy Forum 11 (4), https:// doi.org/10.1515/npf-2020-0040.

Saidel, J. 2017. "Smart Partnership in Contracting: Thriving in a Period of Intense Policy Uncertainty." Nonprofit Policy Forum 8 (2): 121-32.

Saitgalina, M., L. A. Dicke, and P. Birungi. 2020. "Organizational Determinants of Political Involvement in Trade and Professional Membership Associations.” Nonprofit Policy Forum 11 (1), https://doi.org/10.1515/npf-2019-0004.

Seaman, B. A., A. L. Wilsker, and D. R. Young. 2014. "Measuring Concentration and Competition in the U.S. Nonprofit Sector: Implications for Research and Public Policy." Nonprofit Policy Forum 5 (2): 231-59.

Shieh, S. 2018. "The Chinese State and Overseas NGOs: From Regulatory Ambiguity to the Overseas NGO Law." Nonprofit Policy Forum 9 (1), https://doi.org/10.1515/npf-2017-0034.

Simsa, R. 2017. "Repression of the Spanish Protest Movement - Mechanisms and Consequences." Nonprofit Policy Forum 8 (3), https://doi.org/10.1515/npf-2017-0022.

Simsa, R. 2019. "Civil Society Capture by Early Stage Autocrats in Well-Developed Democracies The Case of Austria." Nonprofit Policy Forum 10 (3), https://doi.org/10.1515/npf-2019-0029.

Smith, S. R., and S. D. Phillips. 2016. "The Changing and Challenging Environment of Nonprofit Human Services: Implications for Governance and Program Implementation." Nonprofit Policy Forum 7 (1): 63-76.

Thornton, J., and J. Lecy. 2019. "Good Enough for Government Work? An Incomplete Contracts Approach to the Use of Nonprofits in U.S. Federal Procurement." Nonprofit Policy Forum 10 (3), https://doi.org/10.1515/npf-2019-0037.

Toepler, S. 2018. “Do Benefit Corporations Represent a Policy Threat to Nonprofits?" Nonprofit Policy Forum 9 (4), https://doi.org/10.1515/npf-2018-0021.

Wang, R., and K. AbouAssi. 2021. "The Impact of Medicaid Expansions on Nonprofit Hospitals." Nonprofit Policy Forum, https://doi.org/10.1515/npf-2020-0053.

Young, D. R. 2021. “The First Decade of Nonprofit Policy Forum.” Nonprofit Policy Forum 12 (2): 223-42. 